\title{
PENGEMBANGAN KEWIRAUSAHAAN PEMBUATAN NUGGET IKAN (Fish Nugget) SEBAGAI SALAH SATU USAHA PENINGKATAN PENDAPATAN NELAYAN DI DESA KARANGAGUNG KECAMATAN PALANG KABUPATEN TUBAN
}

\author{
Muhammad Yusuf $^{1 *}$ Miftachul Munir ${ }^{1}$, Hendra Suwardana ${ }^{1}$ \\ Universitas PGRI Ronggolawe Tuban \\ ${ }^{*}$ Korespondensi: ucupabubakar@gmail.com \\ Diterima 7 Mei 2020 / Disetujui 5 Juni 2020
}

\begin{abstract}
ABSTRAK
Salah satu Program pengabdian kepada masyarakat yang kami lakukan di Desa Karangagung kecamatan palang Kabupaten Tuban. Tujuan kegiatan ini untuk pemberdayaan ekonomi masyarakat dengan cara memberikan sosialisasi dan pelatihan pengolahan ikan menjadi nugget, dalam upaya menaikkan nilai jual sebagai sumber tambahan pendapatan masyarakat. Manfaat yang dapat peroleh dari kegiatan pengabdian kepada masyarakat ini yaitu bisa meningkatkan kesadaran masyarakat tentang pentingnya pengembangan inovasi dalam berwirausaha dengan pengolahan bahan-bahan baku yang mudah didapat untuk menjadi produk-produk yang memiliki nilai jual yang lebih tinggi, sehingga bisa dijadikan sumber tambahan pendapatan sebagai pengembangan kewirausahaan dan mengurangi angka pengangguran masyarakat. Metode yang digunakan dalam kegiatan pengabdian kepada masyarakat ini adalah ceramah, demontrasi dan pelatihan kepada masyarakat serta melakukan pendampingan mulai pengolahan ikan menjadi nugget yang lezat sampai pengemasan yang memiliki nilai jual. Hasil kegiatan menunjukkan bahwa masyarakat telah menyadari begitu pentingnya pengembangan inovasi berwirausaha dalam peningkatan ekonomi masyarakat.
\end{abstract}

Kata Kunci: sosialisasi, pelatihan, konsumen, pemasaran

\section{PENDAHULUAN}

Ikan adalah salah satu sumber protein hewani yang banyak dikonsumsi masyarakat, gampang didapat dengan harga yang murah di desa karangagung kecamatan palang kabupaten tuban, yang mayoritas masyarakatnya adalah masyarakat nelayan. Tetapi ikan akan cepat busuk jika tidak segera dilakukan pengolahan. Oleh sebab itu cara pengolahan ikan yang baik dan benar perlu diketahui oleh masyarakat. Untuk memperoleh hasil olahan ikan yang bermutu tinggi sangat diperlukan cara yang baik saat proses pengolahannya, seperti: kebersihannya, menggunakan ikan yang segar, garam yang bersih. bahan dan peralatan yang digunakan, Oleh sebab itu, sangat perlu untuk menerapkan inovasi pengolahan produk produk pangan berbahan dasar Ikan. Karena, dalam memperoleh bahan bakunya sudah sangat tersedia di desa tersebut dan tidak perlu untuk mencari ke desa lain, sehingga perlu dicoba mengembangkan inovasi berbagai produk baru berbahan baku dari ikan. Dengan demikian diharapkan, melalui 
olahan Ikan menjadi nugget ini dapat membantu peningkatan pendapatan, sehingga para Nelayan dan juga masyarakat sekitar di Desa Karangagung kecamatan Palang kabupaten tuban khususnya, dapat merasakan dampak dan manfaat dari kegiatan yang dilakukannya. Berdasarkan pemikiran itu, kami beberapa dosen melakukan kegiatan pengabdian kepada masyarakat untuk memberikan sosialisasi dan pelatihan pengolahan Ikan menjadi nugget yang dikemas dengan bagus dan menjadi produk yang digemari oleh seluruh kalangan dan memiliki nilai jual lebih tinggi.

Ali Khomsan (2004) menyatakan bahwa keunggulan ikan laut terutama bisa dilihat dari komposisi asam lemak Omega-3 yang bermanfaat untuk pencegahan penyakit jantung. Ada beberapa fungsi asal Omega-3 . pertama dapat menurunkan kadar kolestrol darah yang berakibat terjadinya penyumbatan pembuluh darah. Kedua, manfaat lain dari lemak Omega-3 adalah berperan dalam proses tumbuh kembang otak.

\section{METODE PELAKSANAAN}

A. Lokasi dan Waktu Pelaksanaan

Pelaksanaan Kegiatan Pengabdian Kepada Masyarakat ini dilaksanakan di Balai Desa, Desa Karangagung Kecamatan Palang Kabupaten Tuban selama satu bulan

B. Sasaran Pelaksanaan

Program Pengabdian Kepada Masyarakat ditujukan kepada 30 Orang ibu ibu yang tidak bekerja di luar rumah.

C. Bahan dan Alat Yang DigunakanBahan yang digunakan dalam pembuatan nugget ikan adalah daging ikan tenggiri tanpa tulang atau duri, garam $\mathrm{NaCl}$, Benzoat, tepung terigu, tepung maizena, $\mathrm{CMC}$, dan tepung roti, serta bumbu nugget ikan ( bawang merah, bawang putih, pala, penyedap rasa, merica, gula).

Alat yang digunakan yaitu Timbangan kecil, Baskom, Loyang, dandang, Parutan, pisau, blender, Chopper, sendok pengaduk, cetak adonan, cetakan kue, dandang, freezer, kompor, Gas, peralatan penggorengan, dan plastik pembungkus.

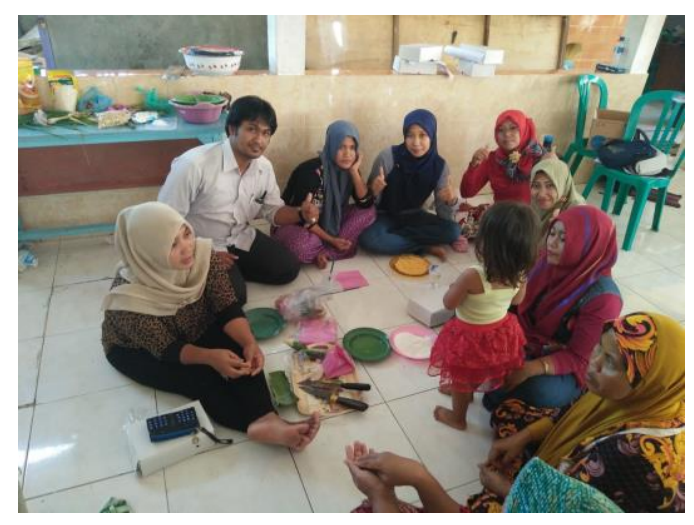

Gambar 1. Awal proses pengolahan nugget ikan tenggiri

D. Metode Pelaksanaan Langkah dalam mewujudkan Sosialisasi dan pelatihan pengolahan singkong kepada masyarakat :

1. Pendekatan kepada pemerintahan desa dan masyarakat setempat.

2. Pendekatan kepada warga masyarakat yang memiliki kemauan dan kepedulian untuk melaksanakannya.

3. Pemetaan permasalahan dari beberapa aspek.

4. Mengidentifikasi Bahan dan alat yang bisa dipakai untuk pembuatan Nugget Ikan.

5. Mengundang warga Masyarakat Desa Karangagung Kecamatan Palang kabupaten Tuban, untuk hadir di balai desa di acara pengabdian kepada masyarakat.

6. Melakukan sosialisasi atau penyuluhan terkait pembuatan Nugget Ikan.

7. Melakukan Pelatihan pembuatan Nugget Ikan yang baik dan benar (efektif dan efesien). 
8. Melakukan evaluasi dengan memberikan post-test.

Mekanisme pelaksanaan ialah dengan pemberian materi, praktek secara langsung dan memberikan pendampingan. Adapun tahapan dan metode dalam pelaksanaan adalah:

1. Ceramah

2. Demontrasi

3. Pelatihan

E. Teknik Pengumpulan Data

Teknik pengumpulan data dengan menggunakan Instrumen yang digunakan untuk menilai keberhasilan dan kebermanfaatan kegiatan pengabdian kepada masyarakat adalah :

1. Membagikan daftar soal pertanyaan pretest dan posttest guna mengukur nilai keberhasilan.

2. Membagikan angket guna mengetahui masukan dan saran peserta pelatihan.

3. Keberhasilan dari kegiatan pengabdian kepada masyarakat ini jika $80 \%$ dari peserta pelatihan mengerti dan paham akan materi dan teknik pembuatan produk Nugget Ikan.

Rincian instrumen yang digunakan pada pelaksanaan kegiatan pengabdian kepada masyarakat :

Tabel 1. Kisi-kisi pre Tes dan Post Tes

\begin{tabular}{|l|l|l|}
\hline No. & Indikator Soal & Butir Soal \\
\hline 1 & $\begin{array}{l}\text { Definisi Nugget } \\
\text { Ikan }\end{array}$ & 1,3 \\
\hline 2 & $\begin{array}{l}\text { Bahan - bahan } \\
\text { pembuatan } \\
\text { Nugget Ikan }\end{array}$ & $\begin{array}{l}\text { Cara Pembuatan } \\
\text { Nugget Ikan }\end{array}$ \\
\hline 4 & $\begin{array}{l}\text { Macam-macam } \\
\text { Olahan Nugget } \\
\text { Ikan }\end{array}$ & 8,10 \\
\hline 5 & $\begin{array}{l}\text { Penyajian Nugget } \\
\text { Ikan }\end{array}$ & 9 \\
\hline
\end{tabular}

Tabel 2. Evaluasi Kegiatan

\begin{tabular}{|l|l|l|}
\hline No. & Indikator Kegiatan & Tolak Ukur \\
\hline 1 & $\begin{array}{l}\text { Jalanya acara } \\
\text { pelatihan }\end{array}$ & $\begin{array}{l}\text { Sesuai } \\
\text { dengan } \\
\text { Jadwal }\end{array}$ \\
\hline 2 & $\begin{array}{l}\text { Peserta yang } \\
\text { hadir }\end{array}$ & $\begin{array}{l}\text { Paling sedikit } \\
70 \%\end{array}$ \\
\hline 3 & Antusias peserta & $\begin{array}{l}\text { Peserta } \\
\text { sangat aktif }\end{array}$ \\
\hline 4 & $\begin{array}{l}\text { Instruktur } \\
\text { Mendemokan } \\
\text { praktik } \\
\text { pembuatan } \\
\text { Nugget Ikan }\end{array}$ & $\begin{array}{l}\text { Secara } \\
\text { berkelompok, } \\
\text { peserta ber- } \\
\text { hasil } \\
\text { membuat } \\
\text { produk } \\
\text { olahan } \\
\text { Nugget Ikan }\end{array}$ \\
\hline 5 & $\begin{array}{l}\text { Instruktur } \\
\text { Mendemokan } \\
\text { praktik } \\
\text { penyajian produk } \\
\text { olahan Nugget } \\
\text { Ikan }\end{array}$ & $\begin{array}{l}\text { Secara } \\
\text { berkelompok, } \\
\text { peserta } \\
\text { berhasil } \\
\text { menyajikan } \\
\text { produk } \\
\text { olahan } \\
\text { Nugget Ikan }\end{array}$ \\
\hline
\end{tabular}

Tabel 3. Hasil Kuesioner

\begin{tabular}{|l|l|c|c|}
\hline No. & Pernyataan & \multicolumn{2}{|c|}{ Jawaban } \\
\cline { 3 - 4 } & Ya & Tidak \\
\hline 1 & $\begin{array}{l}\text { Kecocokan } \\
\text { kegiatan dengan } \\
\text { kebutuhan } \\
\text { masyarakat }\end{array}$ & $100 \%$ & 0 \\
\hline 2 & $\begin{array}{l}\text { Menambah } \\
\text { Motivasi } \\
\text { sesudah } \\
\text { mengikuti } \\
\text { pelaksanaan } \\
\text { pelatihan }\end{array}$ & $100 \%$ & 0 \\
\hline 3 & $\begin{array}{l}\text { Mendorong } \\
\text { Kepedulian } \\
\text { masyarakat }\end{array}$ & $100 \%$ & 0 \\
\hline
\end{tabular}

F. Analisis Data

Dalam menganalisis hasil instrumen yang telah diperoleh adalah menggunakan 
Analisis Statistik Deskriptif. Statistik Deskriptif yaitu metode-metode yang berkaitan dengan pengumpulan dan penyajian suatu gugus data sehingga memberikan informasi yang berguna (Supardi, 2013). Yang berfungsi untuk memberi gambaran terkait objek yang diteliti melalui data sampel dan data yang sudah di analisis, di deskripsikan dengan tabel, diagra, dan gambar.

Kriteria Penilaian:

$$
\text { Nilai }=\frac{\text { Jumlah Skor yang Diperoleh }}{\text { Skor Maksimum }} \times 100
$$

Tabel 4. Evaluasi Pre Test dan Post Test

\begin{tabular}{|l|l|c|}
\hline No. & Nilai & Keterangan \\
\hline 1 & $>80$ & Baik \\
\hline 2 & $>60-80$ & Cukup \\
\hline 3 & $<60$ & Kurang \\
\hline
\end{tabular}

(Sumber: Ali Khosan 2006)

\section{HASIL DAN PEMBAHASAN}

\section{A. Hasil Produk}

Hasil Produk dalam kegiatan

Pengabdian Kepada Masyarakat ini menghasilkan produk "Nugget Ikan Tengiri Istimewa" yang terbuat dari IKandan berbalur tepung yang menghasilkan cita rasa yang istimewa dengan Kemasan yang higenis dan mudah di simpan dan berat produknya 250 gram.

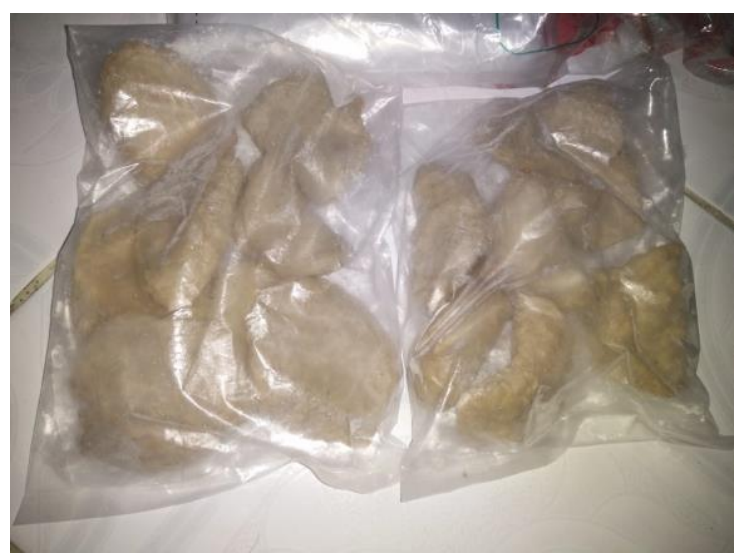

Gambar 2. Hasil produk olahan nugget ikan tenggiri

\section{B. Hasil Pelaksanaan}

1. Lokasi Pelaksanaan Pengabdian

Tempat yang digunakan adalah Balai Desa, Desa Karangagung Kecamatan Palang Kabupaten Tuban.

2. Identitas Sasaran Kegiatan

Kegiatan ini diikuti oleh lbu-lbu yang tinggal di desa Karangagung Kecamatan Palang Kabupaten Tuban. Dengan Jumlah peserta 25 orang Ibu Ibu Rumah tangga yang kebanyakan istri para nelayan setempat.

Kegiatan ini bermaksud menumbuhkan kesadaran masyarakat tentang pentingnya pengembangan inovasi dalam berwirausaha dengan pengolahan bahan-bahan baku yang mudah didapat, untuk menjadi produk-produk yang memiliki nilai jual yang lebih tinggi sehingga bisa di jadikan sumber tambahan pendapatan masyarakat sekitar, khususunya ibu ibu Nelayan.

\section{Hasil Evaluasi Penyuluhan dan Pelatihan}

Evaluasi ini adalah untuk mengetahui perkembangan peserta terkait pengetahuan pembuatan Nugget Ikan, yang dilakukan sebelum dan sesudah pelaksanaan pelatihan pembuatan nugget ikan, peserta diwajibkan untuk menjawab 10 soal Pertanyaan dan Kuesioner yang diberikan oleh tim pelaksana pengabdian kepada masyarakat.

Dalam evaluasi ini menghasilkan beberapa penilaian :

Tabel 5. Nilai Pre Test

\begin{tabular}{|c|c|c|c|}
\hline No. & $\begin{array}{c}\text { Jumlah } \\
\text { Peserta }\end{array}$ & $\begin{array}{c}\text { Presentase } \\
\text { Nilai }\end{array}$ & Keterangan \\
\hline 1. & 12 & $48 \%$ & $\begin{array}{c}\text { Kategori } \\
\text { Kurang }\end{array}$ \\
\hline 2. & 13 & $52 \%$ & $\begin{array}{c}\text { Kategori } \\
\text { Cukup }\end{array}$ \\
\hline
\end{tabular}


Tabel 6. Nilai Post Test

\begin{tabular}{|c|c|c|c|}
\hline No. & $\begin{array}{c}\text { Jumlah } \\
\text { Peserta }\end{array}$ & $\begin{array}{c}\text { Presentase } \\
\text { Nilai }\end{array}$ & Keterangan \\
\hline 1. & 20 & $80 \%$ & $\begin{array}{c}\text { Kategori } \\
\text { Baik }\end{array}$ \\
\hline 2. & 3 & $12 \%$ & $\begin{array}{c}\text { Kategori } \\
\text { Cukup }\end{array}$ \\
\hline 3. & 2 & $8 \%$ & $\begin{array}{c}\text { Kategori } \\
\text { kurang }\end{array}$ \\
\hline
\end{tabular}

Tabel 7. Hasil Kuesioner

\begin{tabular}{|c|l|c|c|}
\hline No. & Pertanyaan & \multicolumn{2}{|c|}{ Jawaban peserta } \\
\cline { 3 - 4 } & & Ya & Tidak \\
\hline 1. & $\begin{array}{l}\text { Kecocokan } \\
\text { bentuk } \\
\text { kegiatan } \\
\text { dengan } \\
\text { kebutuhan } \\
\text { masyarakat }\end{array}$ & $96 \%$ & $4 \%$ \\
\hline 2. & $\begin{array}{l}\text { Peningkatan } \\
\text { Motivasi } \\
\text { setelah } \\
\text { mengikuti } \\
\text { Pelatihan }\end{array}$ & $100 \%$ & - \\
\hline 3. & $\begin{array}{l}\text { Mendorong } \\
\text { Swadaya } \\
\text { Masyarakat }\end{array}$ & $100 \%$ & - \\
\hline
\end{tabular}

\section{KESIMPULAN}

Berdasarkan hasil dan pembahasan, maka dapat disimpulkan sebagai berikut:
1. Peserta pelatihan sudah menguasai konsep-konsep teori pengolahan makanan awetan.

2. Pengetahuan peserta pelatihan sangat meningkat, hal ini dilihat dari hasil evaluasi Pre Test dan Post Testnya.

3. Peserta mampu mempraktekan pembuatan nugget ikan.

4. Antusias Peserta pelatihan sangat tinggi, hal ini terlihat dari keaktifan para peserta.

5. Peserta mampu membuat Kemasan dan label yang menarik, untuk siap dipasarkan ke depannya.

\section{DAFTAR PUSTAKA}

Alamsyah, Yuyun. 2006. Membuat Sendiri Frozeen Food Seafood Nugget. Jakarta: Gramedia Pustaka Different Temperature and Time. Journal of Agriculture and Food Technology, 1 (8): 133-136.

Ali Khomson. 2004. Peranan Pangan dan Gizi Untuk Kualitas Hidup. PT.Gramedia Widiasarana Indonesia: Jakarta.

Suhendra. 2006. Pembuatan Nugget Ikan (Fishnugget) sebagai Salah Satu Usaha Deferensiasi Pengolahan Ikan Di Banda Aceh. 